Karol Kuźmicz

Uniwersytet w Białymstoku e-mail: k.kuzmicz@uwb.edu.pl telefon: 857457153

DOI: 10.15290/mhi.2017.16.02.13

\title{
O tym, jak dawna myśl może żyć współcześnie, czyli refleksje na kanwie Stownika krytyki utopii czasów Oświecenia
}

\author{
(Dictionnaire critique de l'utopie au temps des Lumières, Sous la direction de \\ Bronislaw Baczko, Michel Porret, François Rosset, Edition Georg, Genève \\ 2016, ss. 1407)
}

\section{SUMMARY}

\section{How an old thought can live on today - reflections on the Dictionary of criticism of the Enlightenment's utopias}

Today the importance of the Age of Enlightenment is undeniable. The cult of Reason and Nature not only contributed to the development of culture and science, but also to the development of the state, law and society. According to the Dictionnaire critique de l'utopie au temps des Lumières (Critical Dictionary of Utopia in the Age of Enlightenment), XVIII century utopian thought may carry influence in the present era. This monumental tome, published in Geneva in 2017, is written in French and has more than 1400 pages. It is the product of the joint-effort of more than 50 scholars from different countries, all gathered round the dictionary's creator and editor, Professor Bronislav Baczko (1924-2016). In 2011, Baczko received the Balzan Prize for his studies on the works of J.J. Rousseau and Enlightenment. The dictionary is his crowning achievement and serves as a fitting tribute to his lifetime contribution to philosophy. It contains some 54 terms concerning the Enlightenment's utopia, each having been the subject of critical analysis research.

The issues addressed in the dictionary may be of interest if, not value, to specialist from a wide variety of disciplines including lawyers. In this latter respect the dictionary discusses such legal expressions as: the legislation, the law, the state, the police, crime and punishment, human rights and war and peace. The interdisciplinary nature of the dictionary is not its sole attribute. This is one of the latest studies on Utopia and the Age of Enlightenment, and the message Baczco's delivers is both humanistic and universal.

Key words: philosophy, criticism, utopia, Enlightenment

Słowa kluczowe: filozofia, krytycyzm, utopia, Oświecenie 


\section{Wprowadzenie}

Trudno udzielić jednoznacznej i satysfakcjonującej wszystkich odpowiedzi, zastanawiając się nad tym, która z minionych epok w największym stopniu odcisnęła swoje piętno $\mathrm{w}$ dotychczasowych dziejach ludzkości i nadal na jej losy wpływa. Głosy specjalistów, przede wszystkim zajmujących się danym okresem, wskazują najczęściej na szczególną rolę epoki, którą się sami zajmują. Dodatkowo sprawę komplikuje fakt, związany z koniecznością rozróżnienia wielu kręgów cywilizacyjnych, kulturowych, religijnych, czy narodowych, z perspektywy których można wskazywać na wiekopomne znaczenie danych czasów, ujmowanych przy tym z bardzo subiektywnego punktu widzenia. Poza tym kwestie periodyzacji są bardzo skomplikowane, a wydarzenia i daty związane z początkiem i końcem każdej epoki mają zazwyczaj charakter umowny, przez co, w związku z odpowiednią argumentacją, mogą się zmieniać. Niemniej jednak dawne epoki, których historycznie czas już minął, w mniejszym lub większym stopniu wpływają na teraźniejszość i prawdopodobnie nadal będą kształtować przyszłość. Na pytanie: jak to właściwie robią? odpowiedzi można udzielić na wiele rozmaitych sposobów. Wydaje się, że prym wiodą dwa spośród nich, pierwszy związany z edukacją jako zorganizowanym systemem przekazywania następnym pokoleniom wiedzy i doświadczenia, który niewątpliwie prowadzić ma do postępu. Drugi sposób związany z aksjologią jako pewnego rodzaju systemem ponadczasowych wartości, być może nawet o charakterze uniwersalnym, który wiążą się z realizacją określonych idei, przede wszystkim: społecznych, politycznych, prawnych, ekonomicznych.

Najprostszym jednak sposobem jest potwierdzenie tego, że to, co ważne było kiedyś jest równie ważne dziś. Aktualność bowiem problemów, zwłaszcza tych o charakterze społecznym, z którymi borykają się ludzie od wieków jest w zasadzie niezmienna. Ukazując w powyższym kontekście Słownik krytyki utopii czasów Oświecenia, należy stwierdzić, że dla jego twórców wciąż aktualne są kwestie związane z nowożytnymi utopiami, zwłaszcza epoki Oświecenia. Udowadniają to w sposób oczywisty, poddając krytycznej analizie wybrane pojęcia, które łączą z tekstami utopijnymi. Poruszana $\mathrm{w}$ nich problematyka nie tylko nie straciła ich zdaniem na znaczeniu, ale jest wciąż na nowo interpretowana.

\section{Wspólnota uczonych zgromadzonych wokół Bronisława Baczko}

Słownik jest przy tym jednym $z$ najnowszych, francuskojęzycznych opracowań zbiorowych dotyczących problematyki utopii w myśli zachodnioeuropejskiej. Redaktorami naukowymi tej monumentalnej, gdyż liczącej ponad 1400 stron, księgi są trzej profesorowie uniwersytetów szwajcarskich, dwóch 
pierwszych z Uniwersytetu w Genewie: profesor honorowy Bronisław Baczko i profesor Michel Porret oraz z Uniwersytetu w Lozannie - profesor François Rosset. W tym miejscu warto przypomnieć związki z nauką polską, zwłaszcza socjologią i filozofią Bronisława Baczko, dla którego dzieło to stanowi jakoby Opus Posthumum ${ }^{1}$. Słownik został zresztą zrealizowany dzięki nagrodzonemu w 2011 roku, przez Międzynarodową Fundację Balzana (Prix Balzan) projektowi naukowemu Bronisława Baczko, który od lat jest uważany za autorytet naukowy w zakresie badań myśli Jana Jakuba Rousseau ${ }^{2}$ oraz nad studiami społecznymi i politycznymi obejmującymi czasy Oświecenia, w tym przede wszystkim Rewolucję Francuską.

Porównując niniejszy słownik z wydanym kilka lat wcześniej przez Wydawnictwo Larousse'a - Stownikiem utopii (Dictionnaire des utopies), należy stwierdzić, iż różnice między nimi są znaczące ${ }^{3}$. Pierwszą cechą charakterystyczną opisywanego słownika jest bowiem próba skupienia problematyki utopijnej wokół jednej tylko epoki, czyli Oświecenia. Kolejną wyjątkową cechą jest zaakcentowany już w tytule krytyczny charakter słownika. W sumie krytycznej ocenie naukowej i badaniom zostały poddane 54 kwestie dotyczące utopizmu, ułożone w kolejności alfabetycznej odpowiadającej językowi francuskiemu. Omawiane zagadnienia nie zawierają przy tym typowej encyklopedycznej, czy słownikowej informacji, lecz przypominają raczej artykuł naukowy szeroko omawiający każdy z alfabetycznie wymienionych terminów. Autorzy poszczególnych kwestii przywołują szereg konkretnych przykładów z rozmaitych utopii, dzielą opisywane zagadnienia na podtytuły, opatrują je w liczne ryciny i ilustracje (ok. 160), a całość każdego z nich zamyka indywidualna bibliografia z podziałem na teksty źródłowe i opracowania. Poza tym ten szwajcarski słownik od wcześniejszego francuskiego odróżnia zdecydowanie brak przyznania statusu pojęcia słownikowego, zarówno poszczególnym autorom tekstów utopijnych (nazwiska), jak i samym tekstom o takim charakterze (tytuły).

1 Bronisław Baczko (1924-2016) jeden z najwybitniejszych polskich uczonych w zakresie nauk humanistycznych. Zajmował się przede wszystkim myślą filozoficzną oraz historią idei społecznych i politycznych. W Polsce związany głównie z Wydziałem Filozofii Uniwersytetu Warszawskiego. Uczył i wychowywał wielu wybitnych polskich filozofów i socjologów, takich jak np.: Jan Garewicz, Marek J. Siemek, Zbigniew Kuderowicz, Adam Sikora, Jerzy Szacki, Jerzy Ładyka. W czasie swojego 92-letniego życia dał się poznać, zwłaszcza jako międzynarodowej sławy badacz Jana Jakuba Rousseau, epoki Oświecenia oraz Rewolucji francuskiej. Pod wpływem „wydarzeń marcowych" 1968 r., wyemigrował z Polski ostatecznie wiążąc się ze szwajcarskim Uniwersytetem w Genewie, czyli mieście rodzinnym wspomnianego wyżej myśliciela.

2 Nagroda Balzana przyznawana od 1961 r. za wybitne osiągnięcia m.in. dla rozwoju nauk humanistycznych i kultury, jest uznawana za tzw. szwajcarsko-włoskiego Nobla, gdyż opiera się na działalności dwóch fundacji - jednej działającej w Zurychu, a drugiej w Mediolanie; zob. http://www. balzan.org/en/prizewinners/bronislaw-baczko/research-project-baczko (09.06.2017).

3 Dictionnaire des utopies, sous la direction de M. Riot-Sarcey, T. Bouchet et A. Picon, Larousse 2007, ss. 285. 
Należy podkreślić, że $\mathrm{w}$ pracach nad słownikiem brało udział niemalże 50 badaczy, pochodzący głównie z Europy, ale także Ameryki. Są to: Bronisław Baczko (Uniwersytet w Genewie); Pierre-Yves Beaurepaire (Université de Nice); Pierre-Yves Beaurepaire (Uniwersytet w Nicei); Ugo Bellagamba (Université de Nice); Ugo Bellagamba (Uniwersytet w Nicei); Marc-André Bernier (Université du Québec à Trois Rivières); Marc-André Bernier (Unwersytet w Québec à Trois Rivières); Marie-Françoise Bosquet (Université de La Réunion); Marie-Françoise Bosquet (Uniwersytet w Réunion); Fabrice Brandli (Université de Genève); Fabrice Brandli (Uniwersytet w Genewie); Joël Castonguay-Bélanger (University of British Columbia); Joël Castonguay-Bélanger (Uniwersytet w Kolumbii Brytyjskiej); Marco Cicchini (Université de Genève); Marco Cicchini (Uniwersytet w Genewie); Yves Citton (Université Stendhal-Grenoble 3); Yves Citton (Uniwersytet Stendhal-Grenoble; Deborah Cohen (Université d'Aix-Marseille); Deborah Cohen (Uniwersytet d'Aix-Marseille); Jean Ehrard (Université de Clermont-Ferrand); Jean Ehrard (Uniwersytet w Clermont-Ferrand); Jérôme Ferrand (Université de Grenoble); Jérôme Ferrand (Uniwersytet w Grenoble); Vincenzo Ferrone (Università di Torino); Vincenzo Ferrone (Uniwersytet w Turynie); Laurence Fontaine (CRH-CNRS/EHESS); Laurence Fontaine (CRH-CNRS/EHESS); Vita Fortunati (Università di Bologna); Vita Fortunati (Uniwerstet Boloński); Jean-Marie Goulemot (Université de Tours); Jean-Marie Goulemot (Uniwersytet w Tours); Audrey Higelin-Fusté (Université de Grenoble); Audrey Higelin-Fusté (Uniwersytet w Grenoble); Girolamo Imbruglia (Università di Napoli); Girolamo Imbruglia (Uniwersytet w Neapolu); Claire Jaquier (Université de Neuchâtel); Claire Jaquier (Uniwersytet w Neuchâtel); Catherine Larrère (Université de Paris I, Panthéon-Sorbonne); Catherine Larrère (Uniwersytet Paryski I, Panthéon-Sorbonne); Antoine Lilti (École nationale supérieure, Paris); Antoine Lilti (École Nationale Supérieure w Paryżu); Stéphanie Lojkine (Université d'Aix-Marseille); Stéphanie Lojkine (Uniwersytet d'Aix-Marseille); Robin Majeur (Université de Genève); Robin Majeur (Uniwersytet w Genewie); Jean-Clément Martin (Université de Paris I, Panthéon-Sorbonne); Jean-Clément Martin (Uniwersytet Paryski I, Panthéon-Sorbonne); Didier Masseau (Université de Tours); Didier Masseau (Uniwersytet w Tours); Helder Mendes Baiao (Université de Lausanne); Helder Mendes Baiao (Uniwersytet w Lozannie); Anne-Marie Mercier-Faivrè (Université de Lyon I); Anne-Marie Mercier-Faivrè (Uniwersytet w Lyonie, I); Christian Michel (Université de Lausanne); Christian Michel (Uniwersytet w Lozannie); Vincent Milliot (Université de Caen); Vincent Milliot (Uniwersytet w Caen); Giovanni Paoletti (Università di Pisa); Giovanni Paoletti (Uniwersytet w Pizie); Adrien Paschoud (Université de Lausanne); Adrien Paschoud (Uniwersytet w Lozannie); Paul Pelckmans (Universiteit Antwerpen); Paul Pelckmans (Uniwersytet w Antwerpii); Krzysztof Pomian (CNRS, Uniwersytet Mikolaja Kopernika w Toruniu, Poland); 
Krzysztof Pomian (CNRS, Uniwersytet Mikołaja Kopernika w Toruniu); Michel Porret (Université de Genève); Michel Porret (Uniwersytet w Genewie); Jean-Michel Racault (Université de la Réunion); Jean-Michel Racault (Uniwersytet $\mathrm{w}$ Réunion); Claude Reichler (Université de Lausanne); Claude Reichler (Uniwersytet w Lozannie); Jean-Marc Rohrbasser (INRD - Institut national de recherches démographiques); Jean-Marc Rohrbasser (INRD - Institut National de Recherches Démographiques); François Rosset (Université de Lausanne); François Rosset (Uniwersytet w Lozannie); Stéphanie Roza (Université de Paris I, Panthéon-Sorbonne); Stéphanie Roza (Uniwersytet Paryski I, Panthéon-Sorbonne); Pierre Serna (Université de Paris I); Pierre Serna (Uniwersytet Paryski I); Gabriella Silvestrini (Università degli Studi del Piemonte Orientale «Amedeo Avogadro»); Gabriella Silvestrini (Università degli Studi del Piemonte Orientale «Amedeo Avogadro»); Stéphane Van Damme (European University Institut, Florence); Stéphane Van Damme (Europejski Instytut Uniwersytecki we Florencji); Nathalie Vuillernin (Université de Neuchâtel); Nathalie Vuillernin (Uniwersytet w Neuchâtel); Przemyslaw B. Witkowski (Université de Montpellier III).

Z zadowoleniem powinniśmy przyjąć, że w Słowniku są akcenty polskie, ponieważ do udziału w projekcie zaproszeni zostali także dwaj naukowcy związani w pewien sposób z Polską. Pierwszy z nich to filozof Krzysztof Pomian z Uniwersytetu Mikołaja Kopernika w Toruniu, który w kontekście utopijnym zajmował się kwestią czasu (Temps) ${ }^{4}$. Drugi to posiadający polskie korzenie, specjalista z zakresu literatury francuskiej i historii sztuki, Przemysław B. Witkowski z Uniwersytetu Paula Valéry w Montepellier III, który z kolei podjął się omówienia problematyki dotyczącej ogrodów (Jardins) $^{5}$. W powyższym kontekście, pierwszy zwrócił szczególną uwagę na paradoksalny charakter czasu w utopiach. Z perspektywy dziejowej Krzysztof Pomian zauważył, że kieru-

4 Profesor Krzysztof Pomian swoje niektóre prace napisał w języku francuskim i wydawał za granicą, np. zob. idem, L'ordre du temps, Paris 1984, wyd. polskie: Porządek czasu, tłum. T. Stróżyński, Gdańsk 2014; idem, Collectionneurs, amateurs et curieux: Paris, Venise: XVI-XVIII siècle, Paris 1987, wyd. polskie: Zbieracze i osobliwości: Paryż, Wenecja: XVI-XVIII wiek, tłum. A. Pieńkos, Warszawa 1996; Les archives: de trésor des Chartres au Caran, Paris 1993.

5 Przemysław B. Witkowski opublikował takie prace naukowe, jak np.: 1) Jardins et initiation, [w:] Dictionnaire littéraire des fleurs et des jardins, éd. par P. Auraix-Jonchière et S. Bernard-Griffiths, Paris, Honoré Champion, sous la presse; 2) Six lettres inédites de Jean Potocki (wspólnie z D. Triaire), [w:] Jean Potocki et la trace, éd. par E. Klene, Oxford, The Voltaire Foundation, sous la presse; 3) Noblesse, vertu et charité : Les dames chevalières et les origines de la sociabilité maçonnique en Europe Centrale, [w:] Les femmes et la franc-maçonnerie, des Lumières à nos jours, éd. par C. Révauger, t. 1, XVIIIe-XIXe siècles, Bruxelles, La Pensée et les Hommes, 2011; 4) Jean Potocki et le théâtre de Tulczyn, [w:] Jean Potocki à nouveau, éd. par E. Klene avec la collaboration d'Emiliano Ranocchi et de P. B. Witkowski, Amsterdam - New York, Editions Rodopi 2010; 5) Jean Potocki à la charnière du XVIIIe et du XIXe siècle d'après son cahier de travail personnel et d'autres documents inédits des archives de Kiev, [w:] Jean Potocki ou le dédale des Lumières, éd. par F. Rosset et D. Triaire, Montpellier, Presses universitaires de la Méditerranée 2010. 
nek rozwoju ideologicznego utopii przebiega od ich wolnościowego charakteru ku coraz bardziej totalitarnemu (s. 1306-1313). W ten sposób wnioski wyprowadzone przez polskiego filozofa korespondują zwłaszcza z tymi zawartymi w części dotyczącej pojęcia antyutopii jako wizji sceptycznej, chimerycznej, społecznie bulwersującej i niebezpiecznej, a przy tym bardziej współcześnie popularnej od wizji przedstawianej w tzw. utopii tradycyjnej (s. 129-152). Z kolei Przemysław B. Witkowski analizował różne role, jakie przypisywano ogrodom w tekstach utopijnych (s. 601-628). Słusznie pojęcie ogrodów, łączy on z naturą, w związku z czym, z jednej strony można i należy ją przekształcać, z drugiej strony naturalny ogród jest doskonałością, a mieszkający w nim ludzie są jego integralną częścią. Wydaje się, że ci autorzy w Bibliografii mogliby przynajmniej wspomnieć polskich specjalistów i ich prace związane $\mathrm{z}$ utopiami. Szkoda, że tego nie uczynili, z pewnością mieli ku temu ważne powody i argumenty. W tym temacie, zwłaszcza od Francuzów powinniśmy się uczyć propagowania myśli ojczystej, wskazując przynajmniej, że tym, co dzieje się w nauce światowej przedstawiciele polskiej doktryny, zwłaszcza socjologicznej, polityczno-prawnej i filozofii są bardzo zainteresowani.

\section{Krytycyzm, utopizm, Oświecenie}

Omawianie poszczególnych pojęć niniejszego słownika polega zasadniczo na ujęciu każdego z nich przez pryzmat trzech tytułowych zagadnień. W rezultacie tego, krytycznej analizie badawczej zostały poddane oświeceniowe utopie. Centralnym i najważniejszym jednak zagadnieniem łączącym wszystkie terminy stanowi jednak utopia. Problematyce związanej z definiowaniem właśnie utopii, możemy się już zapoznać we Wprowadzeniu. Redaktorzy zwrócili $\mathrm{w}$ nim przede wszystkim uwagę na etymologię, genezę i paradygmat związany z tworzeniem tekstów utopijnych począwszy od czasów Tomasza Morusa, aż po interesujący ich XVIII w. Baczną uwagę przywiązali przy tym do wyeksponowania wcześniejszych prób opisywania i rozumienia tego pojęcia. $Z$ jednej strony ujmowanego najczęściej jako literacki obraz szczęśliwej krainy, czyli wyidealizowanego miejsca, które realnie nie istnieje (s. 18). Z drugiej zaś strony jako literacką zabawę albo projekt reform o charakterze społecznym - [podkreślenie moje] mających przeobrazić rzeczywistość (s. 22). Powyższe sposoby ujmowania problematyki utopii w sposób hermeneutyczny ma - ich zdaniem - łączyć właśnie ten słownik. Wszyscy, którzy zdecydują się zapoznać z jego treścią, wzbogacą swoją wiedzę nie tylko na temat samej utopii, ale także bogactwa kulturowego epoki Oświecenia (s. 24).

Systematyka poszczególnych terminów słownikowych jest związana z ich kolejnością alfabetyczną odpowiadającą oczywiście językowi francuskiemu. Autorzy poszczególnych pojęć ujmują je w kontekście utopii oświeceniowych, 
które na zasadzie przykładów mają potwierdzać ich obecność i wskazywać powierzoną im wówczas rolę. Faktem jest, że w swoich badaniach Autorzy bardzo często byli zmuszani do wykraczania poza czasy Oświecenia, ze względu na charakter używanej terminologii i możliwości, jakie daje im współczesna interpretacja.

Wśród zagadnień, które zostały poddane tytułowej krytycznej analizie naukowej mamy tzw. klasyczne terminy słownikowe związane $\mathrm{z}$ utopizmem, takie, jak np.: antyutopia, architektura, bieda, ciało ludzkie, czas, dziki, ekonomia, geografia, język, kobieta, komunikacja, literat, luksus, miasto, miłość, natura, niewolnictwo, ogrody, państwo, pejzaż, piraci, podróż, policja, prawa człowieka, prawo, raj, religia, rewolucja, Rewolucja francuska, seksualność, sztuki, śmierć, uczony, ustawodawstwo, własność, zdrowie, zło, zwierzęta, zwyczaje. $\mathrm{W}$ kilku przypadkach mamy do czynienia z zagadnieniami ściśle ze sobą powiązanymi na określonych, logicznych zasadach, tworzących merytorycznie sensowną całość, jak np.: dawne z nowoczesnością, demografię z populacją, książki z bibliotekami, matematykę z geometrią, naukę z techniką, przestępstwa $\mathrm{z}$ karami, rodzinę $\mathrm{z}$ edukacją, wojnę z pokojem, czy wreszcie bardzo ważna kwestia dotycząca uznawania człowieka za poddanego bądź obywatela. Jedno z opisywanych zagadnień odnosi się do sposobów ilustrowania utopii w XVIII w. Jeden $\mathrm{z}$ terminów do tekstu Biblii, a dwa dotyczą bezpośrednio miejsc geograficznych: Ameryki i Paragwaju.

Co ciekawe, zaledwie cztery terminy tegoż słownika są identycznie sformułowane jak we wspomnianym wcześniej francuskim Słowniku utopii. Chodzi o: architekturę, misje jezuickie, rewolucję oraz podróż. Większość jednak omawianych zagadnień można ze sobą powiązać, mimo często niewielkich różnic dotyczących ich sformułowania. Przykład taki stanowić mogą pojęcia: antyutopii z niniejszego słownika z kontrutopią z wcześniejszego. Przedstawione tutaj pojęcie kobiety wiąże się $\mathrm{z}$ bardziej eksponowaną $\mathrm{w}$ tym drugim problematyką feminizmu. $\mathrm{W}$ obu przypadkach inne różnice są jeszcze bardziej subtelne, jak np.: ciało ludzkie a ciało, język a język uniwersalny, nauka i technika a nauki, wojna i pokój a pokój.

Wydaje się, że ze wszystkich terminów analizowanych w słowniku najbardziej zagadkowo brzmi pojęcie: Réseaux (tłum. polskie - sieci), które omawia Pierre-Yves Beaurepaire, w związku ze strukturalizmem Claude'a Lévi-Strauss'a jako antropologiczną teorią odnoszącą się do społecznego życia ludzi ${ }^{6}$. W powyższym kontekście najważniejszą rolę z punktu widzenia utopii odgrywają więzi społeczne i związane bezpośrednio z nimi takie kategorie socjologiczne, jak: przestrzeń społeczna, język i komunikacja.

6 Zob. C. Lévi-Strauss, Antropologia strukturalna, tłum. K. Pomian, Warszawa 2000. 
Każde $\mathrm{z}$ omawianych pojęć posiada indywidualną bibliografię zaproponowaną przez opracowującego je autora. Wszystkie bibliografie łączy jednakowy podział na teksty źródłowe i opracowania. Dodatkowo jeden z aneksów zamykających słownik stanowi tzw. wyciąg źródeł (Répertoire des sources), dopasowujący alfabetycznie ułożone teksty źródłowe $\mathrm{z}$ opisywanymi pojęciami (s. 1377-1397).

Na odrębną uwagę zasługuje fakt przywoływania nie tylko pozycji francuskojęzycznych. Wyraźnie widoczne są zwłaszcza opracowania w języku angielskim, niemieckim i włoskim. Jako autor tekstu źródłowego, jak najbardziej o charakterze utopijnym, pt.: Entretien d'un Européen avec un insulaire du rauyome de Dumocala (Rozmowa Europejczyka $z$ wyspiarzem z królestwa Dumocala) ${ }^{7}$, wymieniony jest kilkukrotnie, w związku z terminem Biblia (s. 210), wojna i pokój (s. 512) oraz miasto (s. 1350) - związany jak najbardziej z XVIII-wieczną Francją - polski król Stanisław Leszczyński (1677-1766)8. Choć nie jest to jedyny wątek dotyczący Polski, to trzeba powiedzieć, że polskojęzycznej literatury autorzy słownika nie zauważają. Najbardziej chyba znanym na Zachodzie tekstem dotyczącym ówczesnej Rzeczypospolitej są Uwagi o rządzie polskim (Considérations sur le gouvernement de la Pologne) Jana Jakuba Rousseau z 1772 r. ${ }^{9}$

Natomiast wśród autorów opracowań, do których odwołują się zdecydowanie najczęściej twórcy słownika jest oczywiście Bronisław Baczko i jego dzieło zatytułowane Światła utopii (Lumières de l'utopie, wydane po raz pierwszy w 1978$)^{10}$ oraz prace pochodzącego z Belgii, znawcy literatury francuskiej Raymonda Trousson ${ }^{11}$.

7 Jest to powiastka utopijna z 1752 r., wydana anonimowo w Nancy pod jednym z pseudonimów, jakimi posługiwał się Stanisław Leszczyński - RDPDDLEDB, czyli Roi de Pologne, Duc de Lorraine et de Barrois.

8 Stanisław Leszczyński po przegranej wojnie sukcesyjnej polskiej (1733-1735) został dożywotnim księciem Lotaryngii, która po jego śmierci jako zaległy posag została przyłączona do Królestwa Francji, gdyż jego młodsza córka Maria Leszczyńska jako żona Ludwika XV Burbona od 1725 r., była królową Francji. Dlatego Stanisław Leszczyński we Francji jest znany przede wszystkim jako królewski teść oraz jako tzw. król-dobrodziej będący mecenasem nauki i sztuki, którego dokonania do dziś docenia się w Nancy.

9 Zob. chociażby wydanie polskie w ramach cyklu „Biblioteka Klasyków Filozofii”: J. J. Rousseau, Uwagi o rzadzie polskim, tłum. B. Baczko, Warszawa 1966.

10 Wydania polskie: B. Baczko, Światta utopii, tłum. W. Dłuski, Warszawa 2016; idem, Rousseau: samotność i wspólnota, Warszawa 1964; idem, Wyobrażenia społeczne. Szkice o nadziei i pamięci zbiorowej, tłum. M. Kowalska, Warszawa 1994; idem, Hiob, mój przyjaciel. Obietnice szczęścia i nieuchronność zła, tłum. J. Niecikowski oraz M. Kowalska (R. XII), Warszawa 2002.

11 W kręgu szczególnych zainteresowań R. Trousson znaleźli się m.in.: Rousseau, Wolter, Diderot, Arnault, Hugo. Z kolei w związku z utopiami zob. idem, D'Utopie et d'Utopistes, Paris 1998; idem, Voyages aux pays de nulle part: histoire littéraire de la pensée utopique, Bruxelles 1999; idem, Religions d'utopie, Bruxelles 2001; idem, Sciennces, techniques et utopies. Du paradies à l'enfer, Paris 2003. 


\section{A jednak "coś" dla prawnika}

Słownik zawiera szereg pojęć związanych bezpośrednio z prawem, do których należą przykładowo: przestępstwa i kary (Crimes et châtiments), prawa człowieka (Droits de l'homme), niewolnictwo (Esclavage), państwo (État), wojna i pokój (Guerre et paix), ustawodawstwo (Législation), prawo (Loi), policja (Police), własność (Propriété). Spośród wymienionych wyżej pojęć szczególnie istotne $\mathrm{z}$ punktu widzenia refleksji na temat prawa mają zdecydowanie dwa ściśle ze sobą związane, a mianowicie: ustawodawstwo i prawo. Pierwszy wiąże się ze sposobami definiowania oraz określeniem miejsca i roli prawa w XVIII-wiecznych utopiach. Jego autor Ugo Bellagamba słusznie ujmuje je w szerszym kontekście intelektualnym epoki Oświecenia, zwłaszcza polityczno-prawnym i filozoficznym. Według niego ówczesny ideał sprawiedliwych praw opiera się najczęściej na życiu zgodnym z Naturą, stworzoną przez Boga i poznawaną Rozumem. W tym kontekście jedynie ustawodawstwo inspirowane przez Naturę może zbliżyć nas do Stanu Natury (L'État de Nature) jako stanu pożądanego. Zadziwiający jest przy tym fakt, że przy analizie obu tych pojęć nie wiązano ich z żadną właściwie teorią prawa naturalnego, choć prawo takie (loi naturelle) stanowiło przecież legislacyjny wzorzec. Faktem jest, że czasy Oświecenia obfitowały w liczne projekty prawne, które miały charakter utopijny. Co ciekawe jako przykład takiego projektu, który bliski jest założeniom klasycznej utopii wskazano na Traktat o wiecznym pokoju Immanuela Kanta (s. 706) ${ }^{12}$. Przeciwniczką takiej interpretacji jest polska neokantystka Maria Szyszkowska, która uzasadnia, że nie jest to projekt utopijny, lecz traktat gotowy do podpisania i wyznaczonego przez Kanta - systematycznego jego realizowania na płaszczyźnie polityki międzynarodowej ${ }^{13}$. Według niej przyszłe państwo, utworzone $\mathrm{w}$ rezultacie podpisania takiego traktatu jako tzw. „państwo celów" będzie doskonałą wspólnotą całej ludzkości, która doprowadzi do harmonijnego połączenia idei homocentryzmu $\mathrm{z}$ ideą socjocentryzmu ${ }^{14}$.

W związku z koniecznością m.in. urzeczywistniania światowego pokoju, pojęcie państwa omawia, także Gabriella Silvestrini. Według niej utopijne myślenie od początku wiązało się z poszukiwaniami modelu państwa idealnego (s. 396), czyli doskonałego głównie pod względem panujących w nim rozwiązań prawno-ustrojowych. Przesłanie praktyczne oświeceniowych utopii należy jej zdaniem powiązać z republiką jako synonimem państwa (s. 401),

12 Tytuł francuski dzieła Kanta to: Projet de paix perpétuelle [1795]; zob. wydanie polskie: I. Kant, Do wiecznego pokoju: projekt filozoficzny, tłum. M. Żelazny, Toruń 1995.

13 Chodzi o tzw. artykuły przygotowawcze (6) i artykuły definitywne (3), które nie tylko są możliwe do urzeczywistnienia, ale także stanowią obowiązkowe zadanie wyznaczone przez rozumną naturę dla całej ludzkości, a wynikające z nakazu prawa moralnego.

14 M. Szyszkowska, Zarys filozofii prawa, Białystok 1994, s. 107. 
którego podstawy funkcjonowania opierać się będą na umowie społecznej, demokracji i wyborach (s. 405 i nast.). Utopie bowiem zapowiadają, że zmiany ustrojowe związane $\mathrm{z}$ republikańskimi ideami są nieuniknione i będą rozprzestrzeniały się po całym świecie, prowadząc do powstawania kosmopolitycznych wspólnot narodów żyjących w pokoju (s. 416).

Innym ważnym z punktu widzenia prawnika pojęciem omawianym w niniejszym słowniku są prawa człowieka (Droits de l'homme). Zajmujący się ich problematyką włoski uczony Vincenzo Ferrone, zastanawia się nad tym, czy istnieje utopia większa i jak dotąd nieosiągnięta, niż ta związana z powszechnością przestrzegania praw człowieka na naszej planecie (s. 315). W prawach naturalnych (droits naturels) upatruje on archetyp współczesnych praw człowieka. W swoim opracowaniu dokonuje, także próby analizy praw obowiązujących w XVIII-wiecznych utopiach. Według niego prawa zarówno determinują utopie, jak i stanowią ich specyficzną część. Przykładowo pisze o obowiązku przestrzegania praw naturalnych, o ich walce ze starym porządkiem (Ancien Régime), o ich walce z niewolnictwem, o tym, że prawa w utopiach mogą przyczyniać się do postępu, być alternatywą dla obowiązujących prawa, czy wreszcie stanowić pomost łączący historię z utopią.

Z kolei Cathrine Larrère, omawiając pojęcie ustawodawstwa, zwraca uwage na istotę praw $\mathrm{w}$ utopiach, podkreślając ich kolektywny charakter, związany przede wszystkim z koniecznością utworzenia wspólnoty dóbr. Drugi wątek, jaki rozważa autorka, dotyczy republikańskiego charakteru utopii, na przykładzie The Commonwealth of Oceana - Jamesa Harringtona z 1656 roku $^{15}$. Podsumowując powyższe kwestie, ostatnim istotnym elementem łączącym prawo i ustawodawstwo z utopijnymi projektami jest ich reformistyczny, a zarazem rewolucyjny charakter. Wniosek jaki nasuwa się nam w sposób jednoznaczny na podstawie niniejszej analizy tych dwóch terminów, sprowadzić należy do następującego stwierdzenia: lepszą przyszłość można jedynie zorganizować zmieniając, czy też wprowadzając racjonalne rozwiązania prawne, które będą zgodne z zawsze doskonałą, sprawiedliwą i wieczną Naturą.

W bardzo interesującym kontekście bezpieczeństwa jako obecnie chyba wartości, która zajmuje $\mathrm{w}$ hierarchii aksjologicznej współczesnych społeczeństw miejsce priorytetowe, Marco Cicchini rozpatruje słownikowe pojęcie policji (Police). Utopijna jej wizja jest chyba prorocza, gdyż ukazuje policję niczym oko, które nieustannie spogląda na wszystko i wszystkich, przypominając przy tym, że nikt nie ucieknie przed prawem i sprawiedliwością (s. 1022).

15 James Harrington (1611-1677) - angielski pisarz polityczny, uważany za jednego z pierwszych teoretyków nowożytnego republikanizmu. Jego najbardziej znany esej opowiada o Oceanii jako utopijnej krainie wspólnoty dóbr. Pod względem organizacyjnym jest ona republiką wojskową, której nadrzędnym celem ma być rozpowszechnianie własnych rozwiązań prawnoustrojowych, uznawanych za uniwersalne i najdoskonalsze na świecie. 
Spośród regulacji prawnych, które w społeczeństwach utopijnych odrywają szczególnie ważną rolę są przepisy dotyczące prawa karnego, ze szczególnym uwzględnieniem sposobów wymierzania kar za popełnione przestępstwa. Badający niniejszą problematykę Michel Porret uważa, że dla podróżnika-narratora utopia jest swoistym laboratorium politycznym związanym $\mathrm{z}$ doskonałością panującego w niej porządku prawego (s. 260). Proponowane w utopiach rozwiązania były uznawane często za reformistyczne i stanowiły postulaty dla przyszłej zmiany obowiązującego prawa. Dodatkowo w rozdziale tym szczególnie interesujące są, po pierwsze, odwołania do idei humanitaryzmu w prawie karnym i C. Beccarii (s. 274-278) ${ }^{16}$; po drugie, potraktowanie J. Benthama jako utopisty (s. 279-281) ${ }^{17}$; i po trzecie, podejście do kary jako zła koniecznego (s. 282-286).

Równie interesujące jest podejście do zagadnienia własności (Propriété). Opracowująca je Stephanie Roza słusznie wiąże je z oświeceniowymi zasadami życia zbiorowego i wspólnoty dóbr opartych na równości (s. 1026). Modna wówczas staje się krytyka własności i związanych z nią ekonomicznie ważnych substytutów bogactwa, głównie: pieniądza i złota. Utopijne podejście do nich wiąże się z koniecznością albo pozbawienia ich znaczenia, albo ich całkowitego zniesienia. $W$ ten sposób utopie na płaszczyźnie ekonomicznej przypisują wartość pozytywną równości w przeciwieństwie do rzeczywistości społeczno-gospodarczej, która od wieków opera się na wciąż pogłębiających się nierównościach ${ }^{18}$.

Zachęcając do wnikliwego zapoznania się ze słownikiem, nie sposób pominąć ilustracji, które w zasadzie towarzyszą wszystkim omawianym w nim zagadnieniom. Nie dziwi, zatem fakt, iż jedno z nich poświęcone jest właśnie sposobom obrazowania XVIII-wiecznych utopii (s. 565-596). Różnego rodzaju: ryciny, rysunki, schematy, projekty od początku towarzyszyły i bez wątpienia wzbogacały teksty nowego gatunku literackiego, jakim okazała się być utopia. Przecież jednym z najważniejszych zadań utopii, obok skłaniania do refleksji, jest pobudzanie wyobraźni przez obraz. Możliwości, jakie dawały utopie rysownikom sprawiały, że obok obrazów przedstawiających świat w sposób realny, niczym fotograficzny, pojawiło się wiele obrazów o charakterze mitycznym, baśniowym, czy fantastycznym. Z pewnością warto je wszystkie obejrzeć, zastanawiając się nad ich tematyką i symboliką. Co ciekawe, analizujący je Stéphane Lojkine, uważa chociażby kartki kolekcjonowane, zwłaszcza przez dzieci z popularnymi dzisiaj Pokemonami za dziedzictwo obrazów utopijnych Panoptikon or the Inspection House.

18

Zob. C. Beccaria, O przestęstwach i karach, tłum. E. S. Rappaport, Warszawa 1959.

Chodzi o projekt reformy więziennictwa zaproponowany przez J. Bentham w dziele z 1791 r.:

szawa 2015. 
stworów (s. 578). Konfigurowanie i projektowanie różnego rodzaju istot, roślin, zwierząt oraz budynków, urządzeń, maszyn, ogrodów to również zasługa utopii. Coraz większe możliwości technologiczne tworzenia i przedstawiania obrazów są jeszcze bardziej otwarte na utopijne treści. Współcześnie chodzi głównie o grafikę komputerową i osiągnięcia kinematografii. Najlepszym tego potwierdzeniem są właśnie ryciny znajdujące się $\mathrm{w}$ niniejszym słowniku, a pochodzące z dwóch oświeceniowych powieści: Podróże Guliwera - Jonathana Swifta (1667-1745) z 1726 roku $^{19}$, oraz wzorowanej na tej pierwszej: Podróży do krajów podziemnych Nielsa Kilma z 1741 roku, której autorem jest duńsko-norweski pisarz Ludvig Holberg (1684-1754) ${ }^{20}$.

\section{Podsumowanie}

Nawet na podstawie jedynie pobieżnej analizy wybranych treści słownika wyraźnie widać, że problematyka podejmowana w utopiach może zainteresować specjalistów z rozmaitych gałęzi prawa, w tym zarówno jego teoretyków, jak i praktyków. Zastanawiając się jednak nad tym, o jakie pojęcia dodatkowo można byłoby wzbogacić słownik, na pierwszym miejscu wskazałbym na triadę wartości związanych z francuskim republikanizmem, czyli: wolność, równość i braterstwo, a następnie wyeksponowal, także takie pojęcia, jak: praca, władza, wspólnota oraz suwerenność i społeczność (społeczeństwo). Niemniej jednak kwestie z nimi związane są obecne w sposób pośredni, a odwołania do nich można znaleźć, rozproszone $\mathrm{w}$ rozmaitych miejscach słownika, przy okazji omawiania poszczególnych jego pojęć. Najtrudniejszym zadaniem stojącym przed jego twórcami bez wątpienia okazała się być krytyka samej utopii, którą bez cienia wątpliwości możemy nazwać konstruktywną, ale na pewno jej nie deprecjonującą. Dokonując krytyki utopizmu nie postawili sobie za cel ukazania go wyłącznie $w$ negatywnym świetle jako koncepcji skrajnie niebezpiecznej, niedorzecznej będącej błędem i pułapką, która ,jest niezgodna z ludzką naturą, ma swoje korzenie $\mathrm{w}$ idealizmie oraz powoduje totalitarne konsekwencje cywilizacyjne, czego przejawem jest monizm kulturowy oraz degradacja bytu osobowego" ${ }^{21}$. Takie skrajne i jednoznacznie negujące utopizm podejście jest oczywiście na gruncie nauki dopuszczalne i zasadne, a przy tym bardzo ważne, ale nie jest też w pełni obiektywne ${ }^{22}$.

Zob. wyd. polskie: J. Swift, Podróże Guliwera, oprac. J. Bocheński i M. Brandys, Warszawa 1972.

Powieść pierwotnie została napisana po łacinie i nosiła tytuł: Nicolai Klimii Iter Subterranueum, a następnie przetłumaczona na język duński. Nie doczekała się jak na razie wydania polskiego.

Ł. Stefaniak, Utopizm: źródła myślowe i konsekwencje cywilizacyjne, Lublin 2011, s. 11 i 206.

Zob. K. Kuźmicz, Kilka uwag w obronie utopizmu, na marginesie pracy Łukasza Stefaniaka, Utopizm: źródła myślowe i konsekwencje cywilizacyjne, „Miscellanea Historico-Iuridica” 2013, t. XII, s. 437-450. 
Jednakże, pewnym mankamentem przy opracowywaniu Słownika wydaje się właśnie zbyt słabe, niż jednak oczekiwane, podkreślenie związków utopii $\mathrm{z}$ totalitaryzmem. Świadczy o tym nie tylko brak takiego terminu, ale także brak wyraźnego akcentu związanego z oddziaływaniem myśli utopijnej na różne totalitaryzmy, jak chociażby komunizm i jego ideologię ${ }^{23}$. W związku z tym wskazana powyżej kwestia i związana z nią problematyka mogłaby być bardziej wyeksponowana, co zrobiono w sposób niepozostawiający żadnych, co do tego faktu wątpliwości, we wspominanym już wcześniej wydaniu Słowniku utopii - Larousse'a. Podana w nim definicja totalitaryzmu odwołuje się przede wszystkim do poglądów dwóch myślicieli, wskazujących na jego bezpośrednie związki z myśleniem utopijnym ${ }^{24}$. Po pierwsze, do zagorzałego obrońcy „społeczeństwa otwartego", czyli Karla R. Poppera ${ }^{25}$, a następnie przywołuje stanowisko dotyczące podziału totalitaryzmów zaproponowane przez Jocoba. L. Talmona, który zwrócił uwagę na konieczność odróżnienia typu nazistowskiego od komunistycznego ${ }^{26}$. Ten drugi rodzaj uznał za bardziej: holistyczny, mesjanistyczny, racjonalistyczny i związany z epoką Oświecenia.

Pewne luki, które zawsze może odnaleźć po wnikliwszym zapoznaniu się z treścią każdego rodzaju słownika, nie zmieniają jednak faktu świadczącego o jego znaczeniu dla światowej nauki początku XXI wieku. Podjętą próbę ujęcia problematyki utopijnej $\mathrm{w}$ formie słownikowej należy jednak uznać za sukces i zachętę do prowadzenia dalszych prac tego typu. Być może również w Polsce znajdą się specjaliści, którzy opracują podobny słownik z perspektywy polskich zainteresowań i badań na temat utopii i utopizmu.

A zatem, bez względu na subiektywne oceny dotyczące materii zawartych w Słowniku oraz jego systematyki, stanowi on wielkie dzieło, które w sposób jednoznaczny łączy epokę Oświecenia z utopizmem. Decydują o tym nie tylko jego rozmiary, ale przede wszystkim poruszone w nim problemy, świadczące o ich aktualności. Autorzy słownika udowodnili, że żyjemy w czasach, które nieustannie czerpią z bogactwa oświeceniowego utopizmu i nadal z tego dziedzictwa będą korzystać, przynajmniej w Europie Zachodniej. W tym względzie, należy się zgodzić z Witoldem Parniewskim, który podkreślił, że Oświecenie dało początek zachodnioeuropejskiej utopii, zarówno tej prospektywnej, czyli

Zob. K. Mannnheim, Ideologia i utopia, tłum. J. Niziński, Lublin 1992; K. Kuźmicz, Filozoficzne przestanki instrumentalizacji prawa w utopii komunistycznej, „Micelanea Historico-Iuridica” 2015, t. XV, z. 1, Studia dedykowane Profesorowi Adamowi Lityńskiemu w 75-lecie urodzin i 50-lecie pracy naukowej, red. P. Fiedorczyk, s. 311-323.

Zob. K. R. Popper, Społeczeństwo otwarte i jego wrogowie, t. 1, Urok Platona, t. 2, Wysoka fala proroctw: Hegel, Marks i następstwa, tłum. H. Krahelska, Warszawa 2006; idem, W poszukiwaniu lepszego świata: wykłady i rozprawy z trzydziestu lat, tłum. A. Malinowski, Warszawa 1997.

26 Zob. J. L. Talmon, Źródła demokracji totalitarnej, tłum. A. Ehrlich, Kraków 2015; oraz Z. Zieliński, Demokracja totalitarna, Lublin 2012. 
tworzonej z myślą o przyszłości oraz tej aktywnej (utopii heroicznej), której kreowana rzeczywistość wskazuje, że wszystko zależy od człowieka, jego rozumu, woli i gotowości do czynu ${ }^{27}$. „I nie ma żadnych przeszkód, by w przyszłości nie pojawił się uniwersalny, doskonały człowiek, mający świadomość swej wolności, a jednocześnie świadomość przynależności do wspólnoty równych, do egalitarnego społeczeństwa" 28 .

A zatem, czy tego chcemy, czy też nie, świat i życie w nim i tak będą się zmieniać. Utopie $w$ przeciwieństwie do antyutopii mają jednak przypominać o tym, że o wiele trudniej jest czynić ten świat lepszym i próbować uszczęśliwiać ludzi, niż nie robić nic w tym kierunku. Patrząc tylko na XX wiek, można powiedzieć, że dużo łatwiej jest niszczyć ten świat, jednocześnie eliminując ludzi bądź ich unieszczęśliwiaćc 9 . Po dziś dzień, utopie właściwie niosą identyczne przesłanie, niczym treść słów przeboju Imagine, w której John Lenon zachęcał do tego, byśmy podobnie jak utopiści wyobrazili sobie lepszy świat, bez żadnych problemów jako „świat bez religii, w którym nie ma własności, a ludzie żyją w braterstwie, dzieląc się ze sobą światem"30.

\section{Bibliografia}

Baczko B., Hiob, mój przyjaciel. Obietnice szczęścia i nieuchronność zła, tłum. J. Niecikowski oraz M. Kowalska (R. XII), Warszawa 2002.

Baczko B., Rousseau: samotność i wspólnota, Warszawa 1964.

Baczko B., Światła utopii, tłum. W. Dłuski, Warszawa 2016.

Baczko B., Wyobrażenia społeczne. Szkice o nadziei i pamięci zbiorowej, tłum. M. Kowalska, Warszawa 1994.

Beccaria C., O przestępstwach i karach, tłum. E. S. Rappaport, Warszawa 1959.

Breczko J., Nowa duchowość, [w:] Wielowymiarowość człowieka, red. K. Kuźmicz, Antropologiczna Szkoła Filozofii Prawa Marii Szyszkowskiej, Białystok 2017.

Dictionnaire des utopies, sous la direction de M. Riot-Sarcey, T. Bouchet et A. Picon, Larousse 2007.

Kant I., Do wiecznego pokoju: projekt filozoficzny, tłum. M. Żelazny, Torun 1995.

27 W. Parniewski, Szkice z dziejów myśli utopijnej (od Platona do Zinowjewa), Łódź 2000, s. 49.

28 Ibidem, s. 49.

29 Zob. K. Kuźmicz, Utopie i antyutopie a totalitaryzm. Refleksje filozoficznoprawne, [w:] O prawie i jego dziejach księgi dwie. Studia ofiarowane Profesorowi Adamowi Lityńskiemu, kom. red. M. Mikołajczyk, J. Ciągwa, P. Fiedorczyk, A. Stawarska-Rippel, T. Adamczyk, A. Drogoń, W. Organiściak, K. Kuźmicz, Białystok-Katowice 2010, s. 1005-1009.

30 Por. J. Breczko, Nowa duchowość, [w:] Wielowymiarowość człowieka, red. K. Kuźmicz, Antropologiczna Szkoła Filozofii Prawa Marii Szyszkowskiej, Białystok 2017, s. 156. 
Kuźmicz K., Filozoficzne przesłanki instrumentalizacji prawa w utopii komunistycznej, „Micellanea Historico-Iuridica” 2015, t. XV, z. 1, Studia dedykowane Profesorowi Adamowi Lityńskiemu w 75-lecie urodzin i 50-lecie pracy naukowej, red. P. Fiedorczyk, s. 311-323.

Kuźmicz K., Kilka uwag w obronie utopizmu, na marginesie pracy Łukasza Stefaniaka, Utopizm: źródła myślowe i konsekwencje cywilizacyjne, „Miscellanea Historico-Iuridica" 2013, t. XII, s. 437-450.

Kuźmicz K., Utopie i antyutopie a totalitaryzm. Refleksje filozoficznoprawne, [w:] O prawie i jego dziejach ksiegi dwie. Studia ofiarowane Profesorowi Adamowi Lityńskiemu, kom. red. M. Mikołajczyk, J. Ciągwa, P. Fiedorczyk, A. Stawarska-Rippel, T. Adamczyk, A. Drogoń, W. Organiściak, K. Kuźmicz, Białystok-Katowice 2010, s. 1005-1009.

Lévi-Strauss C., Antropologia strukturalna, tłum. K. Pomian, Warszawa 2000.

Mannnheim K., Ideologia i utopia, tłum. J. Niziński, Lublin 1992.

Parniewski W., Szkice z dziejów myśli utopijnej (od Platona do Zinowjewa), Łódź 2000.

Pomian K., Collectionneurs, amateurs et curieux: Paris, Venise: XVI-XVIII siècle, Paris 1987, wyd. polskie: Zbieracze i osobliwości: Paryż, Wenecja: XVI-XVIII wiek, tłum. A. Pieńkos, Warszawa 1996.

Pomian K., Krótka historia nierówności między ludźmi na przykładzie Europy, Kraków-Warszawa 2015.

Pomian K., L'ordre du temps, Paris 1984, wyd. polskie: Porządek czasu, tłum. T. Stróżyński, Gdańsk 2014.

Popper K. R., Społeczeństwo otwarte i jego wrogowie, t. 1, Urok Platona, tłum. H. Krahelska, Warszawa 2006.

Popper K. R., Społeczeństwo otwarte i jego wrogowie, t. 2, Wysoka fala proroctw: Hegel, Marks $i$ następstwa, tłum. H. Krahelska, Warszawa 2006.

Popper K. R., W poszukiwaniu lepszego świata: wykłady i rozprawy z trzydziestu lat, tłum. A. Malinowski, Warszawa 1997.

Rousseau J. J., Uwagi o rządzie polskim, tłum. B. Baczko, Warszawa 1966.

Stefaniak Ł., Utopizm: źródła myślowe i konsekwencje cywilizacyjne, Lublin 2011.

Swift J., Podróże Guliwera, oprac. J. Bocheński i M. Brandys, Warszawa 1972.

Szyszkowska M., Zarys filozofii prawa, Białystok 1994.

Talmon J. L., Źródła demokracji totalitarnej, tłum. A. Ehrlich, Kraków 2015.

Trousson R., D'Utopie et d'Utopistes, Paris 1998.

Trousson R., Religions d'utopie, Bruxelles 2001.

Trousson R., Sciennces, techniques et utopies. Du paradies à l'enfer, Paris 2003.

Trousson R., Voyages aux pays de nulle part: histoire littéraire de la pensée utopique, Bruxelles 1999.

Zieliński Z., Demokracja totalitarna, Lublin 2012. 